\title{
Practice of Zero Discharge Project for Desulfurization Wastewater of 1000MW Coal-fired Unit
}

\author{
Wang Renlei*, Yu Jiang, Guo Bowen, and Lan Yonglong \\ Huadian Electric Power Research Institute Co., Ltd, Hangzhou 310030, China
}

\begin{abstract}
The technological process, technical parameters, operation cost and effect of zero discharge project for desulphurization wastewater of $1000 \mathrm{MW}$ coal-fired unit in East China are analyzed. The project mainly adopts the process of softening pretreatment, membrane concentration and evaporation crystallization, the direct cost of per ton water treatment is about $¥ 35.3$, and the final product is high purity industrial salt. This technology can fully realize the zero discharge requirement of desulphurization wastewater, and has good environmental and economic benefits.
\end{abstract}

\section{Project overview}

There are four 1000MW coal-fired units in a large thermal power plant in East China, which are the first stage of $2 \times 1000 \mathrm{MW}$ ultra-Supercritical primary reheat unit and the second stage of $2 \times 1000 \mathrm{MW}$ ultra-Supercritical secondary reheat coal-fired unit. The first phase of the power plant project is equipped with a set of desulphurization wastewater treatment facilities, according to the waste water design of $4 \times 1000 \mathrm{MW}$ unit, the design output is $65.5 \mathrm{~m}^{3} / \mathrm{h}$. Desulphurization wastewater from thermal power plant contains a large number of suspended matter, sulfite, chloride and heavy metals, which have the characteristics of "high hardness, high salt, high suspended matter, high corrosion and heavy metal". It is the most difficult wastewater to be treated in coal-fired power plant at present ${ }^{[1-2]}$. In order to realize the zero discharge of desulphurization wastewater in the real sense, the power plant carried out the zero discharge treatment project of desulphurization wastewater synchronously during the construction of the second phase of the project.

\section{Quality and quantity of desulfurization wastewater.}

The water source of the first and second stage unit is Yangtze River water, and the process water of desulphurization system adopts circulating water of the second stage unit. In order to ensure the equipment anticorrosion effect of desulphurization absorption tower and gypsum quality, the control of chlorine ion in desulphurization wastewater is considered by $20000 \mathrm{mg} / \mathrm{L}$. According to the calculation of coal quality and desulphurization process water quality of the unit, the desulphurization waste water of the first stage unit is $19 \mathrm{~m} 3 / \mathrm{h}$, and that of the second stage unit is $20.4 \mathrm{~m} 3 / \mathrm{h}$, the total amount of desulphurization waste water is $39.4 \mathrm{~m} 3 / \mathrm{h}$. In order to maintain a certain system margin, the zero discharge engineering treatment capacity is designed according to $42 \mathrm{~m} 3 / \mathrm{h}$. The designed influent quality of desulphurization wastewater is shown in Table 1.

Tab.1. Water quality of desulfurization wastewater

\begin{tabular}{|c|c|c|c|}
\hline Number & Project & Unit & Date \\
\hline 1 & $\mathrm{pH}$ & $/$ & $5 \sim 6$ \\
\hline 2 & $\mathrm{SS}$ & $\mathrm{mg} / \mathrm{L}$ & $\leq 10000$ \\
\hline 3 & $\mathrm{Cl}^{-}$ & $\mathrm{mg} / \mathrm{L}$ & 20000 \\
\hline 4 & $\mathrm{SO}^{2-}$ & $\mathrm{mg} / \mathrm{L}$ & 2300 \\
\hline 5 & $\mathrm{Ca}^{2+}$ & $\mathrm{mg} / \mathrm{L}$ & 6000 \\
\hline 6 & $\mathrm{Mg}^{2+}$ & $\mathrm{mg} / \mathrm{L}$ & 2500 \\
\hline 7 & $\mathrm{TDS}$ & $\mathrm{mg} / \mathrm{L}$ & 35000 \\
\hline
\end{tabular}

\section{Zero discharge treatment system}

\subsection{Zero discharge process}

The zero discharge treatment process of desulphurization wastewater is shown in figure 1 , which is mainly composed of softened pretreatment, membrane concentration and TVR evaporation crystallization unit.

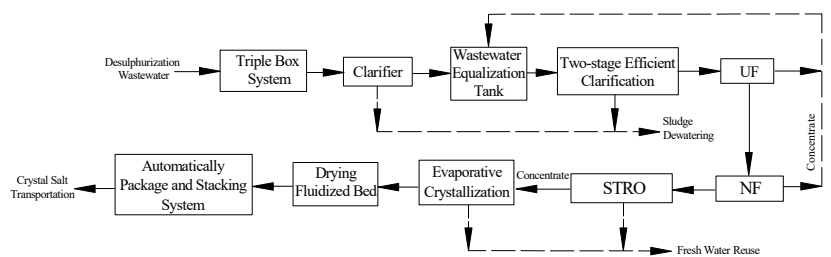

Fig. 1. Zero discharge treatment process of desulphurization wastewater

\footnotetext{
* Corresponding author: wangrlcqu@, 126.com
} 


\subsubsection{Pretreatment process}

The pretreatment system makes use of the desulphurization wastewater treatment facilities of the first phase project and adds lime to the triple header. The technological process is as follows: wastewater buffer tank $\rightarrow$ neutralization/sedimentation/flocculation triple tank $\rightarrow$ integrated clarification tank $\rightarrow$ cleaning tank. The desulphurization wastewater pretreated with lime is discharged into the wastewater equalization tank $\left(2 \times 1000 \mathrm{~m}^{3}\right)$ of zero discharge treatment system by clean water pump.

\subsubsection{Soften treatment process}

The softened treatment process adopts two-stage high efficiency clarification system, the design output is $80 \mathrm{~m}^{3} / \mathrm{h}$, and the hydraulic retention time (HRT) of single-stage system is about $2 \mathrm{~h}$. The technological process is as follows: pretreatment desulphurization wastewater $\rightarrow$ wastewater equalization tank $\rightarrow$ wastewater pump $\rightarrow$ first-class high efficiency clarification system $\rightarrow$ softened pool $1 \rightarrow$ two-stage high efficiency clarification system $\rightarrow$ softened pool $2 \rightarrow$ to concentration system. The two-stage high efficiency clarification system is composed of mixing tank, flocculation tank and inclined tube clarifier. Lime (sodium hydroxide), soda alkali and polyiron are added to the mixing tank of the first high efficiency clarification system to remove calcium and magnesium ions. PAM was added to the flocculation tank and solid-liquid separation was carried out in the inclined tube clarifier. Depending on the water quality, it can be decided whether to add soda, polyiron and PAM to the secondary high efficiency clarification system. The total hardness and turbidity of the effluent from the two-stage high efficiency clarification system are below $200 \mathrm{mg} / \mathrm{L}$ $\left(\mathrm{CaCO}_{3}\right)$ and $5 \mathrm{NTU}$. The $\mathrm{pH}$ of the effluent is adjusted to neutral by adding hydrochloric acid, and then the effluent enters the softened pool 2. The bottom mud of the clarification tank is sent to the plate-frame filter press by sludge pump, and the mud cake is transported out and the filtrate is recovered to the wastewater equalization tank.

\subsubsection{Concentration treatment process}

The concentration treatment process adopts ultra-filtration; nano-filtration and high pressure reverse osmosis system. The technological process is as follows: softened pool $2 \rightarrow$ tube heat exchanger $\rightarrow$ self-cleaning filter $\rightarrow$ ultra-filtration $\rightarrow$ ultra-filtration tank $\rightarrow$ nano-filtration pump $\rightarrow$ nano-filtration security filter $\rightarrow$ nano-filtration $\rightarrow$ water tank $\rightarrow$ transport pump $\rightarrow$ high pressure reverse osmosis security filter $\rightarrow$ high pressure pump $\rightarrow$ high pressure reverse osmosis device $\rightarrow$ concentrated salt water tank $\rightarrow$ to evaporate crystallization system.

The design output of the ultra-filtration device is $2 \times$ $85 \mathrm{~m}^{3} / \mathrm{h}$, the membrane module adopts imported ceramic membrane (CM-151), the material is $\alpha$-alumina, and the average filtration pore size is about $30 \mathrm{~nm}$. The membrane area of a single membrane module is $24.3 \mathrm{~m}^{2}$. A single system is equipped with 24 membrane modules, and the membrane flux of the system is not more than $150 \mathrm{~L} / \mathrm{m}^{2} \cdot \mathrm{h}$. The recovery rate of the system is not less than $90 \%$, the rated transmembrane pressure difference is not more than $0.08 \mathrm{MPa}$ (within one year), and the effluent SDI and turbidity are less than 4 and 1 NTU, respectively. The ultra-filtration effluent enters the subsequent nano-filtration device, and the ultra-filtration reverse washing wastewater returns to the wastewater equalization tank.

The nano-filtration device is configured according to $2 \times 55 \mathrm{~m}^{3} / \mathrm{h}$. It is divided into two stages (9:5), between which there is a booster pump. The design recovery is $70 \%$ and the desalination rate is not less than $97 \%$ (based on sulfate). The membrane flux of the system does not exceed $20 \mathrm{~L} / \mathrm{m}^{2} \cdot \mathrm{h}$. The main function of nano-filtration is to separate monovalent and divalent ions in wastewater and to realize salt separation treatment. The concentrated water of nano-filtration is recovered to the wastewater equalization tank, and the water production enters the subsequent high pressure reverse osmosis system.

The high pressure reverse osmosis device is equipped with $3 \times 27 \mathrm{~m} 3 / \mathrm{h}$, and the spacer tube reverse osmosis system (STRO) is adopted. The recovery rate is $70 \%$, the desalination rate is not less than $97 \%$, the membrane flux of the system is not more than $15 \mathrm{~L} / \mathrm{m} 2 \cdot \mathrm{h}$. The fresh water of STRO is recovered to the boiler supplementary water treatment system, and the concentrated water of STRO enters the evaporative crystallization system. The process mainly realizes the concentration and reduction of desulphurization wastewater, minimizes the treatment scale of evaporative crystallization system, and saves investment and operation cost.

\subsubsection{Evaporative crystallization process}

The evaporation crystallization process adopts the forced cycle crystallization system driven by thermal vapor recompression (TVR), and the treated water quantity is designed according to $2 \times 8 \mathrm{t} / \mathrm{h}$. Main equipment includes concentrated salt water tank, plate heat exchanger, deaerator, flash drum, thermal compressor, forced circulation heater, forced circulating pump, condenser, condensate tank, cyclone, push-type centrifugal dehydrator, mother liquor tank, etc. The moisture content of dehydrated crystal salt is less than $10 \%$.

The drying and packaging process system is designed according to $1.5 \mathrm{t} / \mathrm{h}$. The main equipment includes vibrating fluidized bed steam dryer (matching induced draft Fan and bag filter), automatic metering scale, automatic packaging device, net belt conveyor, manipulator automatic palletizing device, etc. The chemical index of the final product meets the standard for refined industrial salt secondary products specified in Industrial Salt (GB/T 5462-2015), that is, $\mathrm{NaCl} \geq 97.5 \%$, $\mathrm{SO} 42-\leq 0.9 \%,(\mathrm{Ca} 2++\mathrm{Mg} 2+) \leq 0.6 \%, \mathrm{H} 2 \mathrm{O} \leq 0.8 \%$.

\subsubsection{Equipment material}


Due to the high corrosion characteristics of desulphurization wastewater, corrosion resistance should be fully considered in material selection. Efficient clarification system and pools are made of concrete lined fiberglass or glass scales. S22053 stainless steel is selected for overflow parts of mixer, mud scraping machine, pump and tubular heat exchanger. Carbon steel lined ceramics are selected for lime slurry pipe and clarification tank mud pipe. S30408 stainless steel is used for the dosing pipe of alkali, coagulant and coagulant aid. The material of nano-filtration and reverse osmosis security filter is carbon steel lined with S25073 stainless steel. The overflowing part of the fresh water pump in the concentration treatment system is S31603 stainless steel, and the other pumps and process pipes are S25073 stainless steel. The fresh water tank is made of steel inner sprayed polyurea, and the rest of the water tank is made of steel lined glass scales. Gr.12 titanium alloy is selected for overflowing parts of equipment related to evaporative crystallization system, including concentrated salt water pipes. The overflowing parts of automatic packaging device are S32168 stainless steel, and the materials of steam and condensate pipe are S32168 stainless steel.

\section{Operation situations}

\subsection{Softened treatment system}

The effluent quality after two-stage high efficiency clarification system is shown in Table 2. As can be seen from Tab.2, the effluent quality after two-stage high efficiency clarification is stable, which meets the influent quality requirements of the subsequent system.

Tab.2. Effluent quality of two-stage high efficiency clarification system

\begin{tabular}{|c|c|c|c|}
\hline Date & $2019-5-31$ & $2019-6-2$ & $2019-6-5$ \\
\hline $\mathbf{p H}\left(\mathbf{2 5}{ }^{\circ} \mathbf{C}\right)$ & 8.06 & 7.63 & 7.66 \\
\hline $\mathbf{C o n d}(\mathbf{m s} / \mathbf{c m})$ & 59.6 & 56.4 & 61.6 \\
\hline $\mathbf{S O}_{4}{ }^{2-}(\mathbf{m g} / \mathbf{L})$ & 6910 & 5340 & 7600 \\
\hline $\mathbf{C l}^{-}(\mathbf{m g} / \mathbf{L})$ & 13900 & 13400 & 14100 \\
\hline $\mathbf{T u b}^{\mathbf{N}} \mathbf{( \mathbf { T U } )}$ & 3.6 & 4.2 & 2.3 \\
\hline $\mathbf{C a}^{\mathbf{2}}(\mathbf{m g} / \mathbf{L})$ & 41.9 & 49.3 & 57.3 \\
\hline $\mathbf{M g}^{\mathbf{2 +}} \mathbf{( m g / L )}$ & 9.9 & 8.0 & 2.3 \\
\hline
\end{tabular}

\subsection{Concentration treatment system}

Operation and effluent quality of ultra-filtration device are shown in Table 3. The filtration effect of ultra-filtration is very obvious, the turbidity of effluent is stable at $0.1 \sim 0.2 \mathrm{NTU}$, and SDI is kept below 3 .

Tab.3. Operation and effluent quality of ultra-filtration

\begin{tabular}{|c|c|c|c|}
\hline Date & $2019-5-31$ & $2019-6-2$ & $2019-6-5$ \\
\hline $\begin{array}{c}\text { Influent flow rate } \\
\left(\mathbf{m}^{\mathbf{3}} / \mathbf{h}\right)\end{array}$ & 82 & 81 & 80 \\
\hline Influent pressure & 0.13 & 0.12 & 0.13 \\
\hline
\end{tabular}

\begin{tabular}{|c|c|c|c|}
\hline (MPa) & & & \\
\hline TMP (MPa) & 0.06 & 0.06 & 0.07 \\
\hline Tub (NTU) & 0.12 & 0.16 & 0.15 \\
\hline SDI & 2.9 & 2.7 & 2.5 \\
\hline Temp $\left({ }^{\circ} \mathrm{C}\right)$ & 28.5 & 29.0 & 27.6 \\
\hline
\end{tabular}

Operation and effluent quality of nano-filtration device are shown in Table 4and Table 5. The system recovery rate is about $70 \%$, and the removal rate of sulfate is more than $98 \%$.

Tab.4. The operation of nano-filtration

\begin{tabular}{|c|c|c|c|}
\hline Item & $2019-5-31$ & $2019-6-2$ & $2019-6-5$ \\
\hline $\begin{array}{c}\text { Influent flow rat } \\
\left(\mathbf{m}^{3} / \mathbf{h}\right)\end{array}$ & 79 & 80 & 81 \\
\hline $\begin{array}{c}\text { Influent pressur } \\
(\mathrm{MPa})\end{array}$ & 1.15 & 1.16 & 1.16 \\
\hline $\begin{array}{l}\text { First stage pressure } \\
\text { difference (MPa) }\end{array}$ & 0.10 & 0.12 & 0.12 \\
\hline $\begin{array}{c}\text { Second stage } \\
\text { pressure }(\mathrm{MPa})\end{array}$ & 1.20 & 1.22 & 1.21 \\
\hline $\begin{array}{c}\text { Second stage } \\
\text { pressure difference } \\
(\mathrm{MPa})\end{array}$ & 0.12 & 0.11 & 0.12 \\
\hline $\begin{array}{c}\text { Flow rate of } \\
\text { produced water } \\
\left(\mathbf{m}^{3} / \mathbf{h}\right)\end{array}$ & 54 & 55 & 55 \\
\hline
\end{tabular}

Tab.5. Effluent quality of nano-filtration

\begin{tabular}{|c|c|c|c|}
\hline Date & $2019-5-31$ & $2019-6-2$ & $2019-6-5$ \\
\hline $\mathbf{\text { Item }}\left(\mathbf{2 5} \mathbf{\circ}^{\circ} \mathbf{C}\right)$ & 7.25 & 7.19 & 7.11 \\
\hline $\mathbf{C o n d}(\mathbf{m s} / \mathbf{c m})$ & 46.5 & 43.6 & 46.0 \\
\hline $\mathbf{S O} \mathbf{4}^{2-}(\mathbf{m g} / \mathbf{L})$ & 89 & 66 & 97 \\
\hline $\mathbf{C l}^{-}(\mathbf{m g} / \mathbf{L})$ & 15300 & 14600 & 14900 \\
\hline $\mathbf{C a}^{2+}(\mathbf{m g} / \mathbf{L})$ & 20 & 26 & 29 \\
\hline $\mathbf{M g}^{\mathbf{2 +}} \mathbf{( m g / L )}$ & 1.3 & 1.0 & - \\
\hline
\end{tabular}

The operating data of STRO is shown in Table 6 . The system recovery rate and desalination rate are about $70 \%$ and $97.8 \%$ (measured by conductivity). At the same time, the concentration multiple of concentrate is about 2.7 (measured by conductivity).The conductivity of fresh water is about $1000 \mu \mathrm{s} / \mathrm{cm}$, which meets the requirements of influent water quality of boiler supplementary water treatment system.

Tab.6. Operation data of STRO

\begin{tabular}{|c|c|c|c|}
\hline Item & $2019-5-31$ & $2019-6-2$ & $2019-6-5$ \\
\hline $\begin{array}{l}\text { Influent flow rate } \\
\left(\left(\mathbf{m}^{3} / \mathbf{h}\right)\right.\end{array}$ & 26.1 & 26.1 & 26.2 \\
\hline $\begin{array}{c}\text { Influent pressure } \\
\text { (MPa) }\end{array}$ & 6.10 & 6.26 & 5.95 \\
\hline $\begin{array}{c}\text { Influent cond } \\
(\mathrm{ms} / \mathrm{cm})\end{array}$ & 46.5 & 43.6 & 46.0 \\
\hline $\begin{array}{l}\text { Concentrate flow } \\
\text { rate }\left(\mathrm{m}^{3} / \mathbf{h}\right)\end{array}$ & 7.9 & 7.7 & 7.9 \\
\hline $\begin{array}{c}\text { Concentrate cond } \\
(\mathrm{ms} / \mathrm{cm})\end{array}$ & 122.8 & 119.2 & 122.0 \\
\hline $\begin{array}{c}\text { Freshwater flow } \\
\text { rate }\left(\mathrm{m}^{3} / \mathrm{h}\right)\end{array}$ & 18.2 & 18.4 & 18.3 \\
\hline Freshwater cond & $0 . .9$ & 1.2 & 1.0 \\
\hline
\end{tabular}




\begin{tabular}{|c|c|c|c|}
\hline (ms/cm) & & & \\
\hline Influent pH & 7.16 & 7.09 & 7.11 \\
\hline Influent temp $\left({ }^{\circ} \mathrm{C}\right)$ & 29.2 & 29.5 & 28.6 \\
\hline
\end{tabular}

\subsection{Evaporative crystallization system}

The operating data of evaporative crystallization system are shown in Table 7, and the salt production quality is shown in Table 8 . The content of sodium chloride in the produced salt is slightly more than $97.5 \%$. The conductivity of distilled water is less than $20 \mu \mathrm{s} / \mathrm{cm}$ and is recovered to the boiler supplementary water treatment system.

Tab.7. Operation data of evaporative crystallization system

\begin{tabular}{|c|c|c|c|}
\hline Item & $2019-5-31$ & 2019-6-2 & $2019-6-5$ \\
\hline $\begin{array}{l}\text { Concentrate flow } \\
\text { rate }\left(\mathbf{m}^{3} / \mathbf{h}\right)\end{array}$ & 8.0 & 8.1 & 8.0 \\
\hline $\begin{array}{c}\text { Distillate cond } \\
(\mu \mathrm{s} / \mathrm{cm})\end{array}$ & 14.5 & 14.8 & 12.6 \\
\hline $\begin{array}{c}\text { Distillate flow rate } \\
\left(\mathbf{m}^{3} / \mathbf{h}\right)\end{array}$ & 11.3 & 11.1 & 12.2 \\
\hline $\begin{array}{c}\text { Flash tank temp } \\
\left({ }^{\circ} \mathrm{C}\right)\end{array}$ & 110.7 & 111.2 & 111.5 \\
\hline $\begin{array}{c}\text { Flash tank } \\
\text { pressure(Pa) }\end{array}$ & -600 & -610 & -620 \\
\hline $\begin{array}{l}\text { Cyclone underflow } \\
\left(\mathrm{m}^{3} / \mathbf{h}\right)\end{array}$ & 3.6 & 3.5 & 3.7 \\
\hline $\begin{array}{c}\text { TVR pressure } \\
(\mathrm{MPa})\end{array}$ & 0.49 & 0.47 & 0.53 \\
\hline TVR temp $\left({ }^{\circ} \mathrm{C}\right)$ & 175.2 & 176.3 & 179.5 \\
\hline $\begin{array}{c}\text { TVR flow rate } \\
(\mathrm{t} / \mathrm{h})\end{array}$ & 3.7 & 3.6 & 3.9 \\
\hline
\end{tabular}

Tab.8. Salt production quality of evaporative crystallization

\section{system}

\begin{tabular}{|c|c|c|c|c|}
\hline Date & $\begin{array}{c}\mathbf{N a C l} \\
(\mathbf{\%})\end{array}$ & $\begin{array}{c}\mathbf{S O}_{4}{ }^{2-} \\
(\mathbf{\%})\end{array}$ & $\begin{array}{c}\mathbf{C a}^{2+}+\mathbf{M g}^{2+} \\
(\mathbf{\%})\end{array}$ & $\begin{array}{c}\mathbf{H}_{2} \mathbf{O} \\
\mathbf{( \% )}\end{array}$ \\
\hline $2019-6-2$ & 97.7 & 0.27 & 0.12 & 0.18 \\
\hline $2019-6-5$ & 97.6 & 0.36 & 0.13 & 0.20 \\
\hline
\end{tabular}

\section{Investment and operating costs}

The total investment cost of the project is about $¥ 90$ million, and the direct operating costs mainly include chemicals, electricity, steam and film exchange costs. At the same time, the income of selling industrial salt should also be considered. The annual utilization hours of the unit are 5500 hours, the desulphurization wastewater treatment capacity is calculated according to $42 \mathrm{~m}^{3} / \mathrm{h}$, and the operation cost is shown in Table 9 .

Tab.9. Operation cost of zero discharge treatment of desulfurization wastewater $\left(¥ \cdot \mathrm{m}^{-3}\right)$

\begin{tabular}{|c|c|c|}
\hline Item & Cost & Remark \\
\hline Chemicals cost & 35.0 & $/$ \\
\hline Power cost & 3.9 & The cost of power \\
\hline
\end{tabular}

\begin{tabular}{|c|c|c|}
\hline & & $\begin{array}{c}\text { generation is calculated } \\
\text { at } ¥ 0.36 \cdot \mathrm{kWh}^{-1}\end{array}$ \\
\hline Steam cost & 5.0 & $\begin{array}{c}\text { The cost price of steam } \\
\text { is } ¥ 52 \text { per ton }\end{array}$ \\
\hline $\begin{array}{c}\text { Film exchange } \\
\text { cost }\end{array}$ & 1.4 & $\begin{array}{l}\text { The life of the } \\
\text { membrane is calculated } \\
\text { according to } 5 \text { years. }\end{array}$ \\
\hline Salt sale income & 10 & $\begin{array}{l}\text { The price of industrial } \\
\text { salt is } ¥ 400 \text { per ton }\end{array}$ \\
\hline $\begin{array}{c}\text { Total Operating } \\
\text { Costs }\end{array}$ & 35.3 & I \\
\hline
\end{tabular}

\section{Conclusions}

The project was transferred to commercial operation after passing 168 full load performance acceptance tests in May 2019. The system runs stably and each index reaches the design value. From the perspective of operation, the system fully meets the zero discharge treatment requirements of desulfurization wastewater. Therefore, it is feasible to adopt softened treatment, membrane concentration and TVR evaporation crystallization process, which has the characteristics of reliable technology, stable operation and high added value of products. The project has played a good demonstration role in desulphurization wastewater treatment of domestic thermal power plants. However, because the domestic operation performance is relatively small and the accumulation data is not much, the optimization adjustment and cost reduction of the system operation need to be further studied and practiced ${ }^{[3-4]}$.

\section{References:}

1. Nie Xiangxin, Zheng Zongming, Cui Xiaoyang, etc. Research Progress on the Treatment Technologies of Wet Flue Gas Desulfurization Wastewater in Coal-fired Power Plants[J], Electric Power, 2018, 51(12):175-179

2. Ma Shuangchen, Fan Zixuan, Wen Jiaqi, etc. Evaluation on technology of desulfurization wastewater from coal-fired power plant based on fuzzy AHP[J], Chemical Industry and Engineering Progress, 2018,37(11):4451-4459

3. Wei Fei, Liu Jinglong, Wang Te, etc. Research on Zero Discharge Technique of Desulfurization Wastewater in Coal-fired Power Plant[J], Technology of Water Treatment, 2017,43(6):34-36

4. Yang Yuesan, Yuan Zhihua, Zhang Jingrui, etc. Research Progress of Technologies for Zero-discharge of Desulfurization Wastewater from Coal-fired Power Plants[J], Technology of Water Treatment, 2017,43(6):29-33 